EESTI NSV TEADUSTE AKADEEMIA TOIMETISED. 19. KOIDE

KEEMIA * GEOLOOGIA. 1970, Nr. 2

ИЗВЕСТИЯ АКАДЕМИИ НАУК ЭСТОНСКОИ ССР. ТОМ 19

ХИМИЯ * ГЕОЛОГИЯ. 1970, № 2

ELGA MARK-KURIK, TIIU NOPPEL

\title{
ADDITIONAL NOTES ON THE DISTRIBUTION OF VERTEBRATES IN THE SILURIAN OF ESTONIA
}

ELGA MARK-KURIK, TIIU NOPPEL. LISAMÄRKMED SELGROOGSETE LEVIKUST EESTI SILURIS

ЭЛЬГА МАРК-КУРИК, ТИНУ НОППЕЛ. ДОПОЛНИТЕЛЬНЫЕ ЗАМЕЧАНИЯ О РАСПРОСТРАНЕНИН ПОЗВОНОЧНЫХ В СИЛУРЕ ЭСТОНИИ

The recent study on the distribution of the vertebrates in the Silurian is based on the systematic treatment of the cores of two borings, Kingissepa and Kaugatuma on the Isle of Saaremaa (Estonia) as well as on earlier finds. Remains of Agnatha and fishes were obtained in 120 core samples dissolved in dilute acetic acid. The samples were collected at intervals of $0.5-2 \mathrm{~m}$, according to the lithological type of the rocks. More numerous samples were taken near the boundaries of stratigraphic units. The sampling was begun at the lower boundary of the Jaagarahu Stage $\left(J_{2}\right)$. The samples have been collected and treated by T. Noppel and identified mainly by both writers of the present paper. The authors are greatly indebted to V. Karatajutè-Talimaa, Geological Institute, Vilnius, Lithuania, for her kind help in the identification of a part of the material.

The treatment of the new material demonstrates that a lot of thelodont and other vertebrate species have a wider distribution (see Table) than established up to now $\left.{ }^{[1-4}\right]$. Different vertebrates are recorded at lower levels than before: the thelodonts in the middle of the Jaagarahu Stage $\left(\mathrm{J}_{2}\right)$, in the Maasi Beds; some thelodont species, among them Thelodus parvidens Agassiz, in the Rootsiküla Stage $\left(K_{1}\right)$; in the overlying Paadla Stage $\left(\mathrm{K}_{2}\right)$ there have been found six thelodont species and the heterostracan Strosipherus indentatus Pander previously known mainly from the Ohesaare Stage $\left(\mathrm{K}_{4}\right)$. Two new acanthodians have been discovered. One of them. (Gomphodus sp.) occurs in the Paadla Stage $\left(\mathrm{K}_{2}\right)$, the other (Gomphodus? sp.) ranges from the Paadla to the Kaugatuma Stage $\left(\mathrm{K}_{3} \mathrm{~b}\right)$. The osteostracans show a wider distribution, too: from the Rootsiküla Stage to the Aigu Beds of the Kaugatuma Stage $\left(\mathrm{K}_{3} \mathrm{~b}\right)$. In the latter the vertebrates are more abundant than it was suggested up to the present.

The first representatives of Agnatha are discovered in the middle part of the Jaagarahu Stage $\left(\mathrm{J}_{2}\right)$. The earlier finds $\left.{ }^{4}\right]$ were at the top of this stage. The number of the vertebrates of the Jaagarahu Stage is now increased with the presence of Katoporus triangulus Gross. Thus, all the thelodont genera except for Phlebolepis and Goniporus occur, but the number of species is limited. The scales of Logania martinssoni Gross predominate. The samples of the lower part of the Jaagarahu Stage, the Pangamägi Beds, did not contain vertebrate remains. 


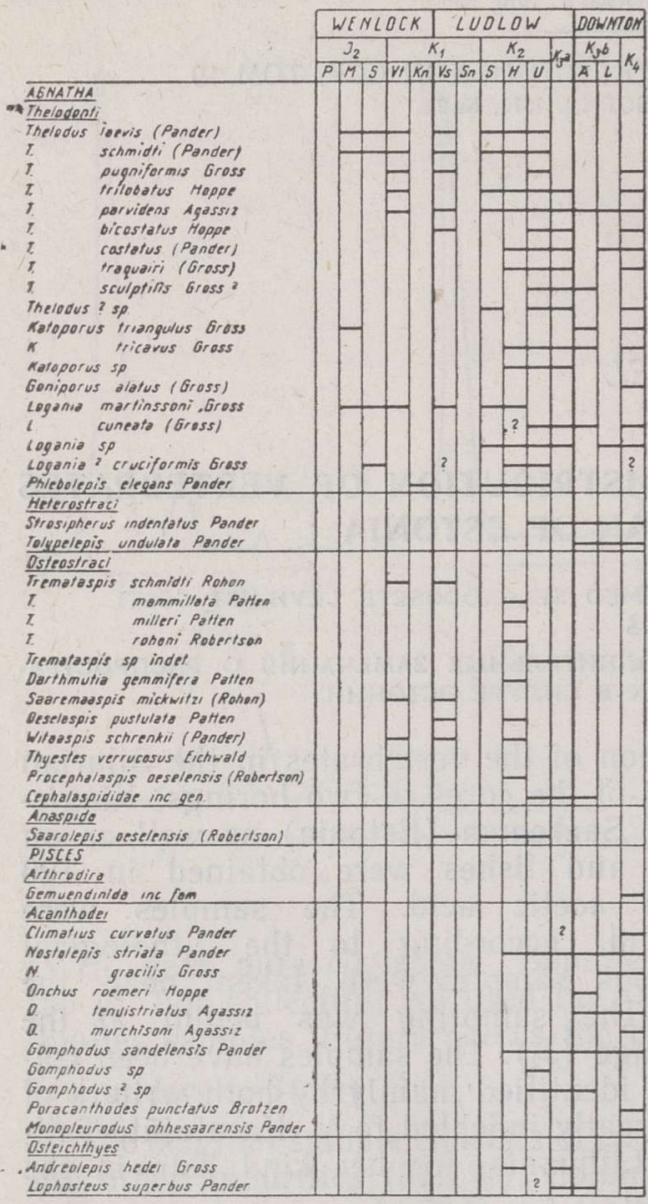

Table. Distribution of the vertebrates in the Silurian of Estonia.

$\mathrm{J}_{2}$ - Jaagarahu Stage, $\mathrm{P}$ - Pangamägi Beds, $\mathrm{M}$ Maasi Beds. S - Saikla Beds; $K_{1}$ - Rootsiküla Stage, Vt - Viita Beds, Kn - Kuusnŏmme Beds. Vs - Vesiku Beds, $\mathrm{Sn}$ - Soeginina Beds; $\mathrm{K}_{2}$ Paadla Stage, S - Sauvere Beds, H - Himmiste Beds, U - Uduvere Beds; $\mathrm{K}_{3} \mathrm{a}$ - Kuressaare Stage: $\mathrm{K}_{3} \mathrm{~b}$ - Kaugatuma Stage, $\ddot{\mathrm{A}}-$ Äigu Beds, L - Lõo Beds; $K_{4}$ - Ohesaare Stage (for stratigraphic subdivision, see $\left[^{5}\right]$ ). Ludlovian-Downtonian boundary. The occurrence of heterostracans is not uncommon in the Paadla Stage as they have been found in the Hemse Beds of the neighbouring area of Gotland, too, $\left.{ }^{6}\right]$ which are perfectly correlated with this stage.

In the Kuressaare Stage $\left(\mathrm{K}_{3} \mathrm{a}\right)$ the number of the thelodonts is somewhat limited. The occurrence of the osteostracans and Lophosteus superbus Pander is noteworthy.

In the Kaugatuma Stage $\left(\mathrm{K}_{3} \mathrm{~b}\right)$ various thelodonts are not scarce, but the acanthodians are more frequent. This stage contains also the osteostracan remains and the scales of rare but characteristic acanthodian Gomphodus? sp. as well as Lophosteus superbus Pander. To the latter 
belong also the remains from the Ohesaare Stage $\left(K_{4}\right)$ identified before as Andreolepis sp. [ [4].

As the recent study shows, a rich thelodont assemblage, earlier known from the Ohesaare Stage $\left(\mathrm{K}_{4}\right)$ only, occurs already in the Paadla Stage, and thus the difference between the Upper Ludlovian and Downtonian vertebrate faunas is not so great as it was suggested previously $\left[{ }^{1,7}\right]$ on a more limited material. Nearly all the same groups are present in both of them. As compared to these faunas the Wenlockian and Lower Ludlovian vertebrate fauna is poorer.

\title{
REFERENCES
}

1. Gross W. 1950. Die paläontologische und stratigraphische Bedeutung der Wirbeltierfaunen des Old Reds und der marinen altpaläozoischen Schichten. Abh. Deutsch. Akad. Wiss. Berlin, Math. - naturwiss. K1., Jg. 1949.

2. Об руче в Д. В. 1958. К биостратиграфии ихтиофаун нижнего и среднего палеозоя. С.СС. Сов. геол., 11.

3. Gros s W. 1967. Uber Thelodontier-Schuppen. Palaentographica, 127 A.

4. Mark-Kurik E. 1969. Distribution of vertebrates in the Silurian of Estonia. Lethaia, 2.

5. К альо Д. Л. (Ред.). Силур Эстонии. Таллин (в печати).

6. Gros s W. 1968. Fragliche Actinopterygier-Schuppen aus dem Silur Gotlands. Lethaia, 1.

7. Obruchev D., Karatajütè-Ta lima a V. 1967. Vertebrate faunas and correlation of the Ludlovian - Lower Devonian in eastern Europe. J. Linn: Soc. (Zool.), 47, 311.

Academy of Sciences of the Estonian SSR, Institute of Geology

EESTI NSV TEADUSTE AKADEEMIA TOIMETISED. 19. KÖIDE KEEMIA * GEOLOOGIA. 1970, Nir. 2

ИЗВЕСТИЯ АКАДЕМИИ НАУК ЭСТОНСКОН ССР. ТОМ 19 ХИМИЯ * ГЕОЛОГИЯ. 1970, № 2

О. $Э$ НЕНН, Э. СНМОН

\section{ГАЗОХРОМАТОГРАФИЧЕСКОЕ ОПРЕДЕЛЕНИЕ СОДЕРЖАНИЯ СПИРТОВ В ВИНАХ}

\author{
O. EISEN, E. SIMON. VEINIDE ALKOHOLISISALDUSE MÄARAMINE \\ GAASIKROMATOGRAAFIA ABIL \\ O. EISEN, E. SIMON. BESTIMMUNG DES ALKOHOLGEHALTS IM WEIN MITTELS \\ GASCHROMATOGRAPHIE
}

Для контроля пищевых продуктов в последнее время широко применяется газохроматографический метод. Ряд работ как в Советском Союзе, так и за рубежом посвящен газохроматографическому определению качества алкогольных напитков. В настоящей работе впервые приво. дятся результаты определения качественного и количественного состава спиртов в вннах, изготовляемых в Әстонской ССР. Для сравнения приводятся данные по одному сорту плодово-ягодного вина и коньяка, изготовляемых за пределами Эстонской ССР.

Использовались хроматографы Хром-1 и Хром-2 с капиллярной колонкой длиной 40 м, диаметром 0,25 мм из нержавеющей стали с триэтиленгликолдибутиратом и насадочными колонками длиной $1,7 \stackrel{\mu}{\text { и }} 6 \boldsymbol{M}$ с наполнителем из $20 \%$ полиэтиленгликоля 4000 на хромосорбе W $(60$ - 